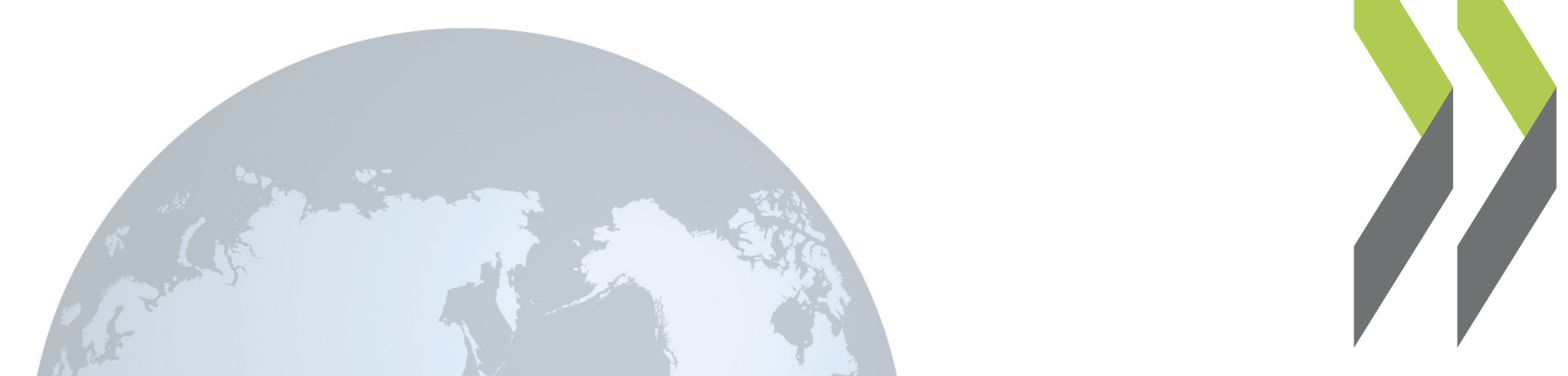

OECD Working Papers on Insurance and Private Pensions No. 11

Implications of Behavioural Economics for Mandatory Individual Account Pension Waldo Tapia, Juan Yermo Systems 


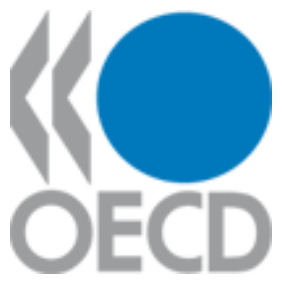

IMPLICATIONS OF BEHAVIOURAL ECONOMICS

FOR MANDATORY INDIVIDUAL ACCOUNT PENSION SYSTEMS

Waldo Tapia, Juan Yermo

July 2007

OECD WORKING PAPER ON INSURANCE AND PRIVATE PENSIONS

No. 11

Financial Affairs Division, Directorate for Financial and Enterprise Affairs Organisation for Economic Co-operation and Development

2 Rue André Pascal, Paris 75116, France

www.oecd.org/daf/fin/wp 


\section{ABSTRACT/RÉSUMÉ \\ Implications of behavioural economics for mandatory individual account pension systems}

In individual account pension systems, members bear the risks and consequences of their investment decisions. If participants behave as predicted by economic theory, such responsibility would be welfareenhancing as members would invest and hold a portfolio of financial assets with a risk-return combination consistent with their investment horizon, degree of risk aversion and the portfolio of other assets they hold, including their human capital and, where relevant, their home. Behavioural economists and empirical researches have shown that in reality members are not particularly good at handling their retirement savings, either because they lack the necessary cognitive ability to solve the optimization problem, because they have insufficient will power to execute it, or even sometimes because they are overconfident. This paper describes the extent to which plan members make active investment decisions in these systems and assesses the policy solutions that have been put forward to facilitate choice. The paper offers a comparative analysis of ten countries that have implemented investment choice in the accumulation stage of their individual account pension system.

JEL codes: J31 G11 G23 G18

Keywords: Pension funds; portfolio preferences; individual choice; individual accounts; investment alternatives; pension plans; investment return; investment limits.

$$
* * * * *
$$

\section{Implications de l'économie des comportements pour les systèmes de pension à comptes individuels obligatoires}

Dans les systèmes de pension à comptes individuels, les membres supportent les risques et les conséquences de leurs décisions d'investissement. Si les participants se comportent comme le prédit la théorie économique, le fait qu'ils assument cette responsabilité doit améliorer leur bien-être car ils réaliseront des investissements et détiendront un portefeuille d'actifs financiers présentant un couple risque-rendement qui sera cohérent avec leur horizon d'investissement, avec leur degré d'aversion au risque et avec les autres types d'actifs qu'ils détiennent, notamment en termes de capital humain et, le cas échéant, d'immobilier. Les économistes du comportement et les recherches empiriques ont toutefois montré que, dans la réalité, les membres des systèmes de pension à comptes individuels ne savent pas particulièrement bien gérer leur épargne retraite, parce qu'ils n'ont pas les connaissances nécessaires pour résoudre le problème de l'optimisation, ou parce qu'ils n'ont pas la volonté suffisante pour mettre en œuvre les décisions nécessaires ou, parfois encore, parce qu'ils pèchent par excès de confiance. Dans ce document, on observe dans quelle mesure les membres des plans font des choix d'investissement actifs et on examine les mesures qui ont été prises par les pouvoirs publics pour faciliter ces choix. On procède, par ailleurs, à une analyse comparative de la situation dans dix pays qui ont introduit des possibilités de choix des investissements, durant la phase d'accumulation, dans leur système de pension à comptes individuels.

JEL codes :G23

Mots clés : Fond de retraite, préférences de portfolio; élection individuelle; comptes individuelles ; alternatives d'investissement; plan de retraite; retours d'investissements; limites d'investissement. 


\section{Copyright OECD, 2007}

Applications for permission to reproduce or translate all, or part of, this material should be made to: Head of Publications Service, OECD, 2 rue André-Pascal, 75775 Paris Cédex 16, France. 


\title{
IMPLICATIONS OF BEHAVIOURAL ECONOMICS FOR MANDATORY INDIVIDUAL ACCOUNT PENSION SYSTEMS
}

\author{
Waldo Tapia, Juan Yermo ${ }^{1}$
}

\section{Introduction}

Seven OECD countries (Australia, Denmark, Hungary, Mexico, Poland, Slovak Republic, and Sweden), have introduced mandatory funded pension plans where individuals bear investment risk during the accumulation phase and can opt for different types of income streams at retirement (primarily annuities or programmed withdrawals). ${ }^{2}$ Such plans are even more popular outside the OECD area. In Latin America, nine countries other than Mexico have them, while in Central and Eastern Europe (excluding OECD countries) the number reaches eight. ${ }^{3}$ Hong Kong (China), India, Kazakhstan, the Russian Federation and Ukraine also have similar systems. In Africa, one country, Nigeria, has introduced such a system, while South Africa is considering it. In total, twenty-nine countries now include individual investment accounts as part of their mandatory pension system. In most cases, these plans are providing benefits that at least partly replace those of the pay-as-you-go (PAYG) financed social security system.

A basic policy question in these new systems is how much choice workers should have over key decisions, such as the choice of provider, choice of investment portfolio, and choice of income stream at retirement. In countries where mandatory individual account systems are large, these financial decisions can determine their standard of living in old age. These decisions are all the more relevant given that participation in these systems is mandatory and that the contribution rate is set by law. If workers need to be obliged to participate in the system and to contribute a certain percentage of their salary, can they be expected to make informed choices over, for example, investment portfolios?

Conventional economic theory suggests that informed economic agents act rationally to maximize their self interest. In theory, optimal investment selection requires that plan members participate actively in the allocation of their investments. Members may have different preferences related to their aversion to risk, and these preferences should be reflected in a different composition of their investment portfolio. Members should be able to choose from a broad range of choices the pension fund and investment portfolio that best matches their personal attitude to investment risks and horizon. They should also have the freedom to switch to another pension fund later if they so choose.

\footnotetext{
${ }^{1}$ The authors would like to thank delegates to the OECD Working Party on Private Pensions for useful comments. The views expressed herein are those of the authors and do not necessarily reflect those of the OECD or the governments of its Member countries. The authors are solely responsible for any errors.
}

Contact information: Waldo Tapia, Private Pensions Unit, Financial Affairs Division, Directorate for Financial and Enterprise Affairs, Organisation for Economic Co-operation and Development, 2, rue André Pascal, Paris, 75775, France. E-mail: waldo.tapia@oecd.org.

${ }^{2}$ Such systems are sometimes called individual accounts. New Zealand is also poised to introduce such a system in July 2007, though workers will be able to opt-out during three months following their automatic enrolment. The UK will introduce a similar system in 2012. In Italy, since January 2007, workers must state if they do not wish their severance payment to be transfered to pension funds.

${ }^{3}$ In Latin America: Chile, Peru, Colombia, Argentina, Uruguay, Bolivia, Mexico, El Salvador and Costa Rica and Dominican Republic. In Central and Eastern Europe: Bulgaria, Croatia, Estonia, Kosovo, Latvia, Lithuania, Macedonia and Slovenia. 
However, a growing research literature in behavioural economics suggests that plan members make systematic errors with respect to their retirement saving, leading ultimately to reductions in economic welfare. While lack of adequate disclosure or knowledge over financial matters may be partially responsible, there is also evidence that even when correcting such problems, individuals are sometimes unable or unwilling (or both) to select an investment portfolio that matches their risk and return preferences. Moreover, in order to be effective in preparing the general population, financial education programmes require a breadth in scope and intensity that can only be achieved over many years and at a high cost. The implementation of investment choice in mandatory individual account systems can therefore have unintended consequences on welfare that should not be ignored.

This paper describes the extent to which plan members make active investment decisions in these systems and assesses the policy solutions that have been put forward to facilitate choice. The first part provides a brief summary of the exiting literature on behavioural economics and individual investment decision-making (primarily from the United States), including the question about whether participants are well placed to make strategic investment decisions with their pension fund assets. The second part offers a comparative analysis of ten countries that have implemented investment choice into their individual account pension system, including some from outside the OECD. The focus is on the accumulation stage, leaving the retirement stage and the integration of the two for future research. The paper, therefore, does not intend to answer the question about the optimal investment portfolio for an individual, as this can only be answered with reference to the retirement stage.

\section{Behavioural economics literature on investment choice}

In individual account systems, members bear the risks and consequences of their investment decisions. If participants behave as predicted by economic theory, such responsibility would be welfareenhancing as members would invest and hold a portfolio of financial assets with a risk-return combination consistent with their investment horizon, degree of risk aversion and the portfolio of other assets they hold, including their human capital and, where relevant, their home. ${ }^{4}$ Following the same idea, much of the discussion concerning the implementation of investment choice assumes that individuals are both exceptionally good decision makers and are able to carry out their investment decisions. In other words, members have the knowledge, willpower and self-control to exercise choice.

Behavioural economists, on the other side, have shown that in reality several obstacles and behavioural challenges compromise good investment decision making. Many individuals are not particularly good at the retirement savings problem either because they lack the necessary cognitive ability to solve the optimization problem, because they have insufficient will power to execute it, or even sometimes because they are overconfident. Surveys and empirical researches suggest that individuals do not follow the traditional assumptions about rational economic decision-making.

This point of view is consistent with the fundamental economic proposition that people can and do try to maximize their self-interest, but it also recognizes that such decisions are often sub-optimal, given available information. ${ }^{5}$ These outcomes have been attributed to various behavioural factors including choice and information overload, unstable or undefined preferences, heuristic decision-making, "framing

\footnotetext{
${ }^{4}$ The optimal asset allocation for a long-term investor has been analyzed by Campbell and Vicera (2002). See Larrain (2007) for a thorough review of the literature (as assumed under the standard utility theory).

${ }^{5}$ Mitchell and Utkus, 2003.
} 
effects" and investment menu design, procrastination and inertia, and overconfidence. Work on utility functions has also highlighted asymmetries in attitudes to probable losses and gains. ${ }^{6}$

\section{Choice and information overload}

Multiple research studies have examined the impact of the number of investment choices upon investor behaviour. Contrary to popular belief, more choice is not always better. Investors can sometimes be prone to choice overload, and simply fail to act. This question has become more relevant in recent years, as financial institutions offer an increasing number of investment options.

Researchers have attempted to determine whether extending the range of choices increases or decreases participation and contribution rates. In sum, the findings indicate that too many investment options can cause information overload, resulting in greater use of the default option and even declines in participation rates. On the contrary, allowing participants to easily evaluate choices and limiting the number of options can raise participation rates.

For example, Iyengar, Jiang and Huberman (2003) found that participation rates in United States 401 (k) pension plans decline as the number of fund options increases. They found that participation rates peaked at $75 \%$ when only two options were offered and they declined steadily to $60 \%$ as the number of options approached $60 .{ }^{7}$ Research in the United State using Vanguard recordkeeping data also found that on average, participation in United State 401(k) plans fell $2 \%$ for every 10 investment options added (Vanguard, 2003). Benartzi and Thaler (2002) found that although retirement plan participants perceive a need to maximise retirement income, they are likely to have difficulty coping with a large number of investment alternatives.

Another research carried out by Agnew (2003) examined the interaction between individuals' financial knowledge and their behaviour relative to the number of investment options. The study found when there was a large number of choices and an increasing number of similar funds, both high-knowledge and low-knowledge participants opted increasingly for the default investment option. ${ }^{8}$

Choice overload also appears to affect asset allocation. Lyengar and Kamenica (2006) show that people reduce their exposure to equities as the menu of funds expands. They estimate that the addition of ten funds increase the fraction invested in money market and bonds funds by 3.28 percentage points

\section{Unstable and undefined preferences}

Although plan members may perceive a need to maximize retirement income, the problem of incoherent preferences for making investment decisions complicates optimal retirement plan design. Much of the research in this area shows that individuals often do not arrive at the decision with firm preferences

\footnotetext{
${ }^{6}$ Kahneman and Tversky, 1979, identified loss aversion, a tendency to weigh losses about twice as much as gains. They also find that individuals judge how their decisions affect incremental gains and losses to their wealth, rather than their total wealth.

${ }^{7}$ The average number of plan options in 401(k) plans in the United States was 19 in 2005, up from 13 in 2000. Despite the growing number of funds, participant use of plan options has remained largely unchanged since 2000. The average participant used 3.6 options in 2005. (Vanguard, 2006). A study carried by Choi et al. (2003) shows that in the United States between $48 \%$ and $81 \%$ of assets in different $401(\mathrm{k})$ plans are invested in the default options.

${ }^{8}$ Utkus (2004) shows that about $80 \%$ of nearly 1,900 DC pension plans in the United States choose a money market or investment contract fund as the default investment option (Vanguard, 2004).
} 
in mind. Rather, individual preferences to risk and time, for example, vary depending on the decision to be made. $^{9}$

For example, Benartzi and Thaler (2002) show that plan participants appear to have relatively weak preferences for the portfolio they elect. This was found in experiments where workers were given a choice between holding their own portfolio, the portfolio of a median participant in their plan, and the portfolio of the average participant. They found that participants seemed to be happier with the portfolio constructed as the statistical average of their co-workers' behaviour than with the portfolio they themselves had originally selected.

An important issue to consider is whether the seeming lack of firm preferences evidenced by the these studies is symptomatic of a much deeper problem of lack of understanding of the choices offered, insufficient knowledge over basic financial issues or simply recognition of the complexity of the portfolio choice problem in an inter-temporal setting.

\section{Heuristic decision-making}

Other systematic violations of rationality that affect investment decision have been attributed to specific shortcuts or 'heuristics'. Heuristics are simple rules of thumb which have been proposed to explain how people make decisions, come to judgments and solve problems, typically when facing complex problems or incomplete information.

Investors are confronted daily with a large amount of information that should allow them to make informed and economically rational decisions. The decision making process, however, is not a strictly rational one where all relevant information is collected and objectively evaluated. Rather, the decision maker takes mental 'short cuts' (Kahneman and Tversky 1974). There may be good practical reasons for adopting a heuristic decision making process, particularly when there is time pressure, or when other factors make fully evaluating all choices difficult.

To illustrate, investors who have the possibility to allocate part of their pension savings between different options are confronted with a complex sequence of choices. First, they have to decide whether to invest in the default option or in other fund. Second, they have to decide in how many funds to invest in. Third, they have to choose in which funds to invest in. Finally, they have to decide what percentage should be invested in each fund. In such situations, Benartzi and Thaler (2001) find support for the existence for the " $1 / \mathrm{n}$ " strategy (and other "naïve diversification strategies"), which leads participant to split their contribution equally amongst " $n$ " funds offered by the plan. Huberman and Jiang (2006) also find that the use of the $1 / \mathrm{n}$ rule is related to the ease of applying it.

Benartzi and Thaler (2001) studied the relationship between the menu of investment choices and the eventual pattern of asset holdings across different classes. Using a database of 170 retirement saving plans in the United States, they showed that in schemes offering a majority of stock funds most contributions were invested in stocks, while in schemes offering a majority of fixed income funds most saving were invested in interest-bearing securities. Furthermore, they find a positive relationship at the plan level between the fraction of equity funds offered by the plan and the fraction of individual portfolios invested in equities.

Another evidence of heuristic decisions is individuals' reliance on recent past performance when choosing mutual funds (Patel et al., 1991). Investors often select funds based on returns over the last 5 years or less, even though over such short periods over-performance could be simple due to luck. Benartzi

\footnotetext{
${ }^{9}$ Benartzi and Thaler, 2002.
} 
(2001) also finds that members' high allocation to company stock in 401(k) plans was based on simple extrapolation of the company's historic return.

Faced with a large number of complex decisions, members frequently rely on heuristics, or "rules of thumb", that serve to reduce the complexity of assessing probabilities into simpler judgments. In many circumstances, members appear to be influenced by factors that are not necessarily relevant to the outcome, and consequently their choices may not correspond to their underlying risk attitudes. More worryingly in the investment arena, heuristics may result from individual being unable to asses risk in term of probabilities. ${ }^{10}$

\section{"Framing effects" and investment menu design}

Another bias in decision-making is a result of the fact that many participants are easily swayed by the way in which saving and investment question are presented or "framed" for them. If a number of different investment options are presented, issues such as numbering and the order in which they appear will affect the choice made. Several studies about discretionary 401(k) plans have emphasised the fact that employees' choices are strongly influenced by "framing effects" (Mitchell and Utkus, 2004). In a panel data study, Brown et al. (2007) found that the number and mix of investment option has an important effect on overall asset allocation.

Benartzi and Thaler (1999) also find that simple changes in the way information is presented can affect individuals' choices. According to their experiments, investors react differently according to whether the long-run results or short-run results are presented. Again, the question that can be asked about all these findings is whether they are simply evidence of insufficient cognitive ability or knowledge to solve complex portfolio optimization decisions.

\section{Procrastination and inertia}

An important behavioural bias identified by researchers affecting active investment decision is the impact of the inertia and procrastination. When plan participants face complex decisions required to make investment choice, inertia (keep the things as they are) or procrastination (put the decision off until tomorrow) affects their decisions, leading to sub-optimal choices. ${ }^{11}$

Investment decisions are susceptible to procrastination because plan members will not always make decisions when short-run costs are involved even if the long-term gains are substantial. Procrastination becomes more relevant when the pension plan design allows investment choice and members face substantial planning or informational costs in making investment decisions. When plan members desire to change their investment allocation, they must first decide which pension fund is the optimal savings strategy. This complex decision involves fixed costs in acquiring the information needed to exercise choice.

The problem of procrastination and inertia is closely related to that of "bounded-self control" identified by Mullainathan and Thaler (2000) in retirement saving decisions. That is, people try to save for retirement, but they too often prove to be limited in their capacity or desire to execute intentions. It would

\footnotetext{
${ }^{10}$ Examples of risk myopia abound in the United State behavioural economics literature. One of the egregious employees' perception of their company's stock as less risky than or equally risky as, a well-diversified equity fund (Mitchell and Utkus, 2004)

${ }^{11}$ Choi, Laibson, Madrian and Metrick, 2003; Madrian \& Shea, 2001; Mitchell \& Utkus 2003.
} 
seem that while people intellectually "understand" the benefits of a specific behaviour, and they may even have some idea of how to get started, they have difficulty implementing their intentions. ${ }^{12}$

In addition, the human tendency toward procrastination about unpleasant activities often leads to inertia or "status quo bias". Inertia plays a large role in investment decision process. A sizeable percentage of participants in traditional DC plans stay with their initial investment selection for many years. ${ }^{13}$ Thus, inertia often results in a failure to rebalance or reallocate their portfolios. This idea is supported by Benartzi \& Thaler (2002) who show that participants rarely rebalance their investment portfolios after joining plans.

Research carried out by Weber (2003) suggests that inertia is explained by the decision of plan members to avoid retirement related decisions, which inherently involve contemplating unpleasant factors including the negative aspects of aging and ultimate death. Benartzi and Thaler (2007) argue that the failure to rebalance portfolios (or inertia in the asset allocation) may arise from investor shunning potential regret of reallocation their portfolio and observed the new investment choices underperforms the original ones.

\section{Overconfidence}

Another bias in decision making is a result of the fact that many individuals are overconfident. Overconfidence is the tendency for people to overestimate their knowledge, abilities and the precision of their information, for that reason investment decisions become based on conjecture rather than fundamental value. A large experimental literature finds that individuals are usually overconfident (see for example Fischoff, 1982), that is, they believe their knowledge is more precise than it actually is. Since overconfidence directly influences decision making, it is natural to ask how overconfidence will affect the future benefits of members.

In the psychology literature, there are two factors that can contribute to overconfidence: the illusion of knowledge and the illusion of control. The illusion of knowledge occurs when one has a large amount of information, but automatically assumes that the information has been interpreted correctly so that it can be used wisely. Many investors do not have the skills or training to interpret information correctly. The illusion of control refers to the belief that one has control over uncontrollable events.

In a research setting, overconfidence can be detected in several ways. Barber and Odean (2000) directly assessed two competing theories: (1) the rational expectations framework suggests that investors will trade when the marginal benefit of doing so will be equal to or will exceed the marginal cost of the trade; (2) the overconfidence framework predicts that investors are overconfident in their abilities and trade in excess to their own detriment. They conducted a comprehensive study of the trading histories of more than 60,000 households with accounts at a large discount brokerage between 1991 and 1996. They found that the overconfidence framework best explains trading behaviour. Specifically, they found that investors who traded most frequently earned $11.4 \%$ net return whereas those who traded least frequently earned $18.5 \%$ net return. In other worlds, it is not portfolio selection, but rather the cost of trading and the frequency of trading that explained the poor investment performance. They concluded that "these high levels of trading can be at least partly explained by a simple behavioural bias: People are overconfident, and overconfidence leads to too much trading". ${ }^{14}$

\footnotetext{
${ }^{12}$ Mitchell and Utkus, 2003.

${ }^{13}$ Ameriks and Zeldes, 2004.

${ }^{14}$ Barber and Odean, 2000.
} 


\section{The regulation of investment choice in mandatory individual account systems}

The acknowledgement of the weaknesses of the rationality assumption has led some to suggest a libertarian paternalistic approach to pension plan design (Sustein and Thaler, 2005). The key aspects of pension plan design are the range of investment options, the design of the default strategy option and the extent of freedom of choice. A review of the international experience shows different approaches to these regulatory issues.

\section{Investment options}

A central decision about the design of a system of mandatory individual accounts with investment choice concerns the appropriate balance between individual choice with a high degree of flexibility on the one hand, and the simplicity of a restricted menu of choices on the other. The ten countries studied can be classified into two main groups, depending of the extent of investment choice they permit:

- Some countries as Sweden and Australia allow relatively unlimited investment choices.

- Three Latin American countries (Chile, Mexico and Peru) and four Central and Eastern European countries (Estonia, Hungary, Latvia and Slovakia) and Hong Kong (China) offer a more limited range of choices.

The menu design in the Swedish mandatory individual account system (the so-called Premium Pension System, PPS) is similar to the 401(k) in the United States. Policymakers deliberately chose an investment policy that would allow a broad choice in the pension premium system. Swedish managers may register maximum 25 funds with a wide variety of investment alternatives such as equity, mixed or balanced, interest and life cycle funds. An individual may choose a maximum of 5 different funds, and the number of fund changes is unrestricted. Since the beginning of the system the range of funds offered to plan members has broadened rapidly. In the first round of fund choice in 2000, over 450 funds were registered in the system. At the end of 2006, about 82 managers had registered 776 funds in the system (see Table 1). Each fund manager had an average of 9 funds and the fund manager with the most funds had 37 funds registered.

Table 1: Number of funds in the Premium Pension System, Sweden

\begin{tabular}{lcccccc}
\hline & \multicolumn{2}{c}{2004} & \multicolumn{2}{c}{2005} & \multicolumn{2}{c}{2006} \\
\cline { 2 - 7 } & Number & $\begin{array}{c}\% \text { of total } \\
\text { funds }\end{array}$ & Number & $\begin{array}{c}\% \text { of total } \\
\text { funds }\end{array}$ & $\begin{array}{c}\text { Number } \\
\text { funds }\end{array}$ \\
\hline \hline Equity funds & 471 & $71 \%$ & 513 & $72 \%$ & 571 & $73 \%$ \\
Mixed / Balanced funds & 52 & $8 \%$ & 51 & $7 \%$ & 53 & $7 \%$ \\
Interest funds & 114 & $17 \%$ & 117 & $17 \%$ & 122 & $16 \%$ \\
Life cycle funds & 26 & $4 \%$ & 30 & $4 \%$ & 30 & $4 \%$ \\
Total & 663 & & 711 & & 776 & \\
\hline
\end{tabular}

Source: Premium Pension Authority, 2006

Participants in Australia's compulsory superannuation system also face a staggering array of potential choices. Investment options are commonly grouped under four broad headings: growth, balanced, capital stable and capital guaranteed. By June 2006, around 50\% of superannuation funds (of 428 funds) encourage participants to make investment decisions about where to allocate their contributions (Chart 1). On average, participants face 35 different investment alternatives. However, as shown in Chart 2, the number of options varies considerably between different superannuation funds. Retail funds offer the most 
extensive menu of choices with more than 88 options, on average. On the other hand, the number of available offers by corporate, public sector and industry funds are typically rather limited, with just 6,7 and 10 options, on average, respectively. ${ }^{15}$

Investment choice by fund type in the Superannuation system, June 2004 - June 2006

Chart 1: \% of entities offering investments choice (2004 - 2006)

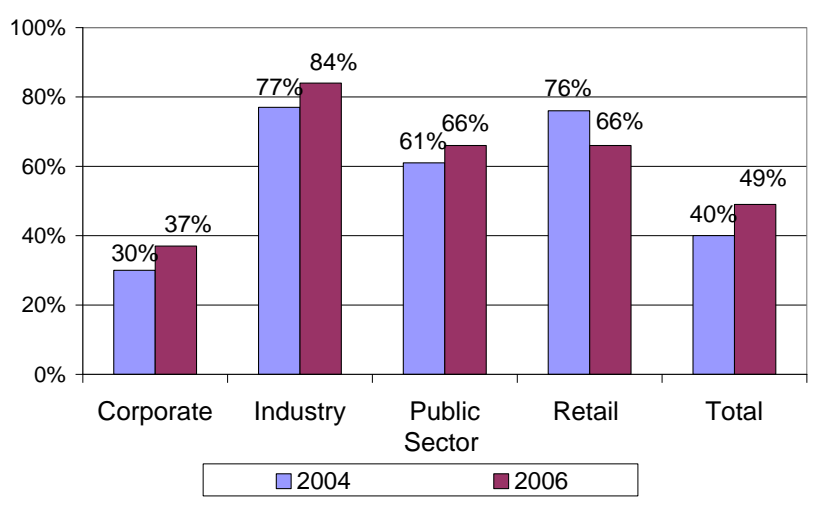

Source: Australian Prudential Regulation Authority Chart 2: Average number of investment choices offer
per entity ${ }^{16}(2002-2006)$

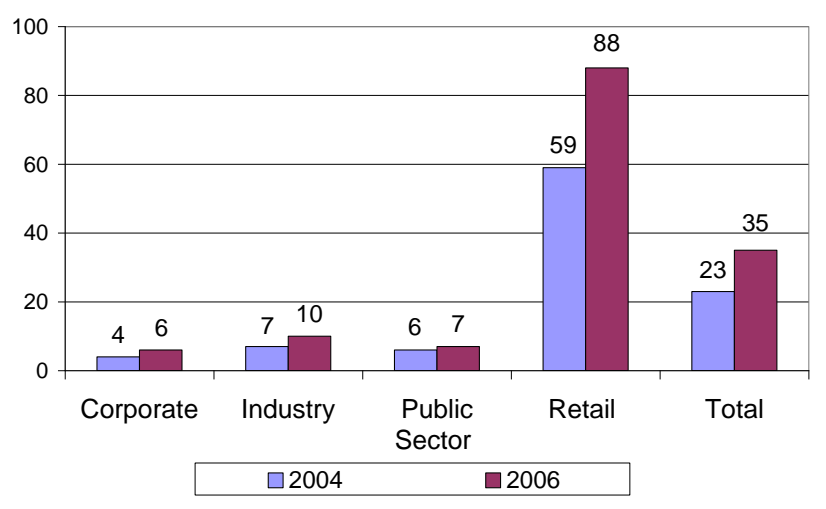

Source: Australian Prudential Regulation Authority

In the Latin American and Central and Eastern European countries the investment menu offers far fewer choices than in Australia or Sweden. The typical approach is to allow fewer than five lifestyle funds, offering varying allocations to bonds and equities, which attempt to provide some age-related profiling. In these systems, members must also make two sequential choices. First, they choose provider (Pension Fund Administrator, AFP), and only then they choose a specific lifestyle fund. This contrast with the situation in Sweden where individuals choose directly a mutual fund offered in the Premium Pension System.

Latin American policymakers have been the most cautions with respect to investment choice. During the first two decades of the Chilean mandatory pension system, participants were not permitted to make asset allocation decisions. This approach was taken in order to reduce administrative costs and complexity. In 2000, the government required that AFPs open a more conservative fund for retirees or near-retirees. Two years later, each fund administrator was permitted to expand the number of investment offerings from two to five in order to allow participants to diversify their asset allocations. Under this new investment menu, each AFP offers up to five funds, called simply A, B, C, D and E. The funds are differentiated by the proportion of their portfolio invested in variable income securities and fixed income. An adequate range is given between the minimum and the maximum limits to enable the portfolio manager to optimize the investment in each fund (see Table 2).

\footnotetext{
${ }^{15}$ Corporate funds are employer-sponsored superannuation funds generally restricted to employees of the sponsoring employer; Industry superannuation funds cover mainly employers within a certain industry; Public sector funds are schemes that cover public sector employees; and, Retail funds are funds offered to the public and to employers by financial service providers.
}

\footnotetext{
${ }^{16}$ The average number of investment choices offered per entity refers to those entities that have investment choice.
} 
Table 2: Maximum and minimum limit by pension fund in Chile

\begin{tabular}{|c|c|c|}
\hline \multirow{2}{*}{ Fund } & \multicolumn{2}{|c|}{ Limit on investment in equities (as a percentage of total assets) } \\
\hline & Minimum limit & Maximum limit \\
\hline A & $40 \%$ & $80 \%$ \\
\hline B & $25 \%$ & $60 \%$ \\
\hline C & $15 \%$ & $40 \%$ \\
\hline D & $5 \%$ & $20 \%$ \\
\hline $\mathrm{E}$ & \multicolumn{2}{|c|}{ Mainly fixed income instruments } \\
\hline
\end{tabular}

More recently, Mexico and Peru have also introduced investment choice in their mandatory individual account pension system. Since 2005, after 8 years of operations, Mexican participants are able to select from two investment options. One of the options invests only in fixed income securities (SIEFORE 1), while the other one can invest up to $15 \%$ in equities through principal protected notes (SIEFORE 2). Both investment alternatives are allowed to invest up to $20 \%$ in foreign securities.

As from November 2005, the number of investment alternatives for each fund administrator in Peru was extended from one to three (conservative, mixed and aggressive). These funds are differentiated mainly by the proportion of their portfolio invested in variable income securities, fixed income securities, derivative instruments and short term instruments. Maximum limits, as a percentage of the value of each fund, were laid down for each class of instrument according to the type of fund, hence there is a clear differentiation between the three funds. Table 3 shows the maximum investment limit for each fund and each instrument.

Table 3: Maximum limit by pension fund in Peru

\begin{tabular}{cccc}
\hline \multirow{2}{*}{ Instrument } & \multicolumn{2}{c}{ Investment limit (as a percentage of total assets) } \\
\cline { 2 - 4 } & Conservative fund & Mixed fund & Aggressive fund \\
\hline Variable instruments (Equities) & $10 \%$ & $45 \%$ & $80 \%$ \\
Fixed income instruments (> 1 year) & $100 \%$ & $75 \%$ & $70 \%$ \\
Derivative instruments & $10 \%$ & $10 \%$ & $20 \%$ \\
Short term instruments & $40 \%$ & $30 \%$ & $30 \%$ \\
\hline Source: Superintendencia de Banca, Seguros y AFP & &
\end{tabular}

As in Latin American countries, the menu design of their individual account systems in CEE countries allows participants to choose only between a restricted number of options. In Estonia (since July 2002), Hungary (since January 2007), ${ }^{17}$ Latvia (since January 2003), and Slovakia (since January 2005) pension funds administrators offer three different lifestyle investment alternatives according to the risk level of pension funds: Conservative, Balanced and Aggressive option. As in Latin America, the funds are differentiated mainly by the proportion of each fund invested in equities. Table 4 gives the different limit in equities for each fund and each country.

\footnotetext{
${ }^{17}$ Hungary implemented an investment choice scheme in its mandatory pension fund system in January 2007. The new scheme is voluntary for the first two years. From beginning 2009, implementation will become mandatory.
} 
Table 4: Maximum limit by pension fund in CEE countries

\begin{tabular}{ccccc}
\hline \multirow{2}{*}{ Investment Strategy } & \multicolumn{2}{c}{ Investment limit in equities (as a percentage of total assets) } \\
& Estonia & Hungary & Latvia & Slovakia \\
\hline \hline Aggressive & $50 \%$ & No limit & $30 \%$ & $80 \%$ \\
Balanced & $25 \%$ & $40 \%$ & $15 \%$ & $50 \%$ \\
Conservative & $0 \%$ & $10 \%$ & $0 \%$ & $0 \%$ \\
\hline
\end{tabular}

In all these countries, each investment option is addressed to members of a specific age group. Yet, in the three countries different investment strategies were designed for the same group of members. There is a wide variation among the aggressive investment alternative, where the equity exposure varies for example, from $30 \%$ (in Latvia) to $80 \%$ (in Slovakia) or 100\% in Hungary. Younger members are expected to choose the "aggressive' option, while older ones are expected to choose the "balanced" options. Yet, young members who actively choose the aggressive option in Estonia, with an equity exposure of $50 \%$ follow the same investment strategy as members of medium age in Slovakia, who choose the balanced option, with the same equity exposure.

Similar evidence can be found in the new mandatory occupational pension system in Hong Kong (China), the Mandatory Provident Fund ${ }^{18}$ (MPF), where employees can choose among a restricted number of lifestyle funds offered by the MPF providers chosen by their employer. Generally, MPF providers offer on average 5-7 fund choices varying from conservative to aggressive, but can offer as few as two or as many as 29 choices, according to Watson Wyatt MPF Watch Survey. As at 30 Dec 2006, there were 40 MPF providers in the market that provided an aggregate of 316 constituent funds, $70 \%$ of them offered an equity exposure over $70 \%$ (see table 5 ).

Table 5: Number of funds in the Hong Kong Mandatory Provident Fund (MPF) System

\begin{tabular}{cccc:ccc}
\hline \multirow{2}{*}{ Type of fund } & \multicolumn{3}{c}{2001} & \multicolumn{3}{c}{2006} \\
\cline { 2 - 7 } & $\begin{array}{c}\text { Equity } \\
\text { exposure }\end{array}$ & $\begin{array}{c}\text { Number of } \\
\text { funds }\end{array}$ & $\begin{array}{c}\text { \% of total } \\
\text { funds }\end{array}$ & $\begin{array}{c}\text { Equity } \\
\text { exposure }\end{array}$ & $\begin{array}{c}\text { Number of } \\
\text { funds }\end{array}$ & $\begin{array}{c}\% \text { of total } \\
\text { funds }\end{array}$ \\
\hline Capital Preservation Fund & $0 \%$ & 51 & $17 \%$ & $0 \%$ & 40 & $13 \%$ \\
Money Market Fund & $0 \%$ & 10 & $3 \%$ & $0 \%$ & 5 & $2 \%$ \\
Guaranteed Fund & $31 \%$ & 40 & $13 \%$ & $15 \%$ & 31 & $10 \%$ \\
Bond Fund & $0 \%$ & 8 & $3 \%$ & $0 \%$ & 18 & $6 \%$ \\
Balanced Fund & $57 \%$ & 137 & $46 \%$ & $70 \%$ & 134 & $42 \%$ \\
Equity Fund & $90 \%$ & 54 & $18 \%$ & $97 \%$ & 88 & $28 \%$ \\
Total funds & $46 \%$ & 300 & & $58 \%$ & 316 &
\end{tabular}

Source: MPF Authority.

\section{Design of the default option}

Policymakers are beginning to learn that the design of the default investment option is extremely important in mandatory individual systems, since a significant percentage of participants will likely fail to

\footnotetext{
${ }^{18}$ The Mandatory Provident Fund system came into operation on December 1, 2000. It is a compulsory, defined contribution retirement saving scheme managed by private sector fund managers.

${ }^{19}$ The name of the funds is only generic names. Different schemes may adopt different names for their funds.
} 
make an active choice. The different experiences around the world show that the default option is addressed mainly to two different groups. The first group includes members that feel that they have neither the knowledge nor the commitment to design and manage their own portfolio, whereas in the second group are those members that feel that have the commitment to design and manage their own fund portfolio but insufficient knowledge to do so.

In Australia, less attention has been given to the design of the default option, with primary consideration given to establishing a process for selecting a default fund that will minimize costs to employers rather than necessarily ensuring the default option is the 'best' alternative for employees who do not exercise choice. ${ }^{20}$ In Sweden, the default option's investment strategy was structured in order to reflect the asset allocation of an average investor in the system. ${ }^{21}$ On the other hand, in CEE countries, policy makers decided that the default option should be structured as a non-risky option. Finally, in LatinAmerican countries, the default investment strategy follows a life-cycle profile, which means moving to lower risk funds as the pension saver gets older.

The regulation in Australia's Superannuation system does not prescribe any specific asset allocation for the default option. In practice, the default alternative of different superannuation funds tends to be a balanced fund, but it varies widely in terms of asset allocation. In June 2006, the average equity allocation in the default option was between $64 \%$ in corporate funds and $45 \%$ in retail funds (average 56\%). On the other hand, the allocation to fixed income securities varied between $14 \%$ in industry funds and $23 \%$ in retail funds (average 16\%). ${ }^{22}$ This result suggests that a large number of superannuation fund members will obtain large differences in the investment performance just because of the differences of the menu design of their default investment option.

The Swedish government established two pension funds in the Premium Pension System, one being a default fund for participants who did not wish to make an active investment choice (Premium Saving Fund), and a second for participants who wanted to make an active choice but also wanted the government involved in the asset management (Premium Choice Fund). However, individuals who opt out of the default fund are prohibiting from opting back into the fund.

During the implementation of the Premium Pension System reformers suggested that the Premium Saving Fund (default option) would be a low-risk fund mostly invested in interest earning assets. But policymakers worried that such strategy would have a negative effect on the distribution of benefits, as low-income workers were most likely to take the default. Consequently, the default option fund's investment strategy was reformulated to mirror the asset allocation of an average investor in the system. By the end of 2005, the standard portfolio of the Premium Saving Fund had the following structure: $83 \%$ in equities, $9 \%$ in fixed income securities, $4 \%$ in hedge funds and $4 \%$ in private equity funds. This relatively aggressive investment strategy may be explained by the fact that the system collects only $2.5 \%$ of worker's salary and provide benefits on top of a generous social security system (60\% net replacement rate)

In Estonia, Latvia and Slovakia, all contributions are invested in the most conservative strategy ( $0 \%$ of equity exposure) until the participant designates an alternative pension fund. The MPF system in Hong Kong follows a similar situation. The governing rules specify the Capital Preservation Fund ( $0 \%$ of equity exposure) for those members who failed to exert their choice of investment portfolio. The fund has

\footnotetext{
${ }^{20}$ Brown at al., 2004.

${ }^{21}$ Sundén, 2004.

${ }^{22}$ In June 2004, the average equity allocation in the default option was 53\%, while in fixed income securities was $15 \%$.
} 
restrictions on investments and is a low-risk fund, with the investments being in cash and short-term debt securities.

The reasoning for such regulations may be that those unable to make choice may also be the most risk averse. Another conventional argument for selecting a conservative default fund is to give members time to "make up their minds". Thus, policymakers invest pension saving in a fixed income fund under the expectation that at some point in the future, participant will make their own appropriate investment choice.

The drawback with both arguments is based on the emerging body of research on inertia and procrastination among members. In those pension plans with different investment options, research have shown that many members are passive decision makers. Thus, the default option selected by policy makers become de facto the member's choice. Selecting a conservative strategy as a default option could be inconsistent with two financial principles: the existence of an equity risk premium, and the principle that younger individuals are able to assume greater equity market risk than older individuals. ${ }^{23}$

Unlike CEE countries, the design of the default portfolio in Latin American countries was to select a more aggressive default option for younger participants and a less aggressive one for older participants. In Chile, for example, members who do not make an active choice are assigned to balanced funds based on a participant's expected time horizon until retirement and gender. The rule for assigning members to one of the five funds involves dividing them into three age groups, where younger members are assigned to a fund with more equities and older member to one with a higher allocation to fixed income instruments. Members can choose funds in the two extremes of the spectrum (fund A and fund E), but the default funds are only those in between (see Table 6).

Table 6: Assignment by age band for members in Chile who do not choose a fund (the default option is shaded)

\begin{tabular}{|c|c|c|c|}
\hline \multirow[b]{3}{*}{ Investment options } & \multicolumn{3}{|c|}{ Age band } \\
\hline & 1-age group & 2-age group & 3-age group \\
\hline & $\begin{array}{l}\text { Men and women up to } \\
35 \text { year old. }\end{array}$ & $\begin{array}{c}\text { Men from } 36 \text { to } 55 \\
\text { years and women from } \\
36 \text { to } 50 \text { years. }\end{array}$ & $\begin{array}{c}\text { Men from } 56 \text { years and } \\
\text { women from } 51 \text { and } \\
\text { pensioners. }\end{array}$ \\
\hline \multicolumn{4}{|l|}{ Fund $A$ (up to $80 \%$ of equities) } \\
\hline \multicolumn{4}{|l|}{ Fund B (up to $60 \%$ of equities) } \\
\hline \multicolumn{4}{|l|}{ Fund C (up to $40 \%$ of equities) } \\
\hline \multicolumn{4}{|l|}{ Fund D (up to $20 \%$ of equities) } \\
\hline Fund $\mathrm{E}$ (no equity exposure) & & & \\
\hline
\end{tabular}

The design of the default option in Mexico and Peru points in a similar direction. However, in these countries members are divided only in two age bands. In Mexico, the SIEFORE 1 is the default strategy for those members older than 56 years old who make no choice, while the SIEFORE 2 admits only members with an age lower than 55 years. In Peru, the regulations also consider that those members who do not select an investment strategy when joining the Pension System will be assigned to one according to their age. The rule established for assigning members dividing them into two groups age-bands, with members younger than 60 years old being assigned to Mixed Fund and members older than 60 years are automatically assigned to the fund with the highest level of fixed income, the Conservative Fund.

\footnotetext{
${ }^{23}$ Younger members have more years of labour income with which to recover from the potential losses associated with stock ownership. Older members, on the other side, may prefer pension funds with minimal risk in order to minimize the fluctuations in the value of their old-age benefits.
} 
Another aspect of the default option is the choice of manager. Together with Sweden, Latvia was also until recently the only country where the default option was publicly managed. In Latvia, since the beginning of the individual account pension scheme (July 2001) until the end of 2002, the State Treasury was the single manager in the system. From January 2003, members were allowed to choose between different investments allocations in different private fund administrators and the Treasury managed the default fund. The government recently decided that the State Treasury would cease management of investment plans and all the assets under its management and its members would be distributed among private fund managers. The exact criteria for a participant who has not intended to make an active choice of pension fund will be provided in the near future.

\section{Freedom of Choice}

A distinctive element of the investment choice schemes implemented in Latin American countries is that they do not allow full freedom of choice. There exist restrictions according to the age of the participants. In Chile, the limitation is for male members over 55 years old and female members over 50 years old. Pensioners may choose only the Funds C, D and E, which have a lower relative risk, whilst members who are within 10 years or less of the legal retirement age may access to the fund type $\mathrm{B}, \mathrm{C}, \mathrm{D}$ and E. ${ }^{24}$ In Peru, there is freedom of choice for all participants, except for those over 60 years old and retirees. Both may opt only for one of the two investment allocation with lower relative risk, conservative and mixed fund. Finally, in Mexico, SIEFORE 1 (investment only in fixed income securities) is open mainly to those members of the Pension System older than 56 years old. However, it is also open to all other members younger than 56 years old, who voluntarily chose to invest their resources in this fund. On the other hand, SIEFORE 2 (up to 15\% of equity exposure) admits only those members with an age lower than 55 years old.

The aim of this regulation is to prevent pensioners and members close to retirement from taking high risks with their mandatory savings. This regulation limits the exposure of older members to the volatility of variable income instruments. It may also be explained by the potential moral hazard caused by state guarantees for minimum pensions.

The existing regulations in the other countries do not impose any particular restriction on choice. This implies that all members, regardless of their age, are allowed to choose the investment portfolio of their preference. The lack of a specific regulation on portfolio choice could have an important impact on the retirement savings of older members. Unexpected fluctuations in the equity market just before retirement can harm permanently the benefits of those older members who have placed their contributions in the more aggressive funds. On the other hand, workers can expect to live for another twenty years or more after they retire. A complete reallocation towards fixed income instruments, therefore, may only be optimal at a later age.

\section{International Evidence on investment choice}

\section{Extent of active choice}

The U.S. evidence, reviewed in the previous section, demonstrates that although members of retirement plans have the option to exercise active choice, most of them frequently fail to make an investment decision.

\footnotetext{
${ }^{24}$ Both groups will be able to choose any of the five Funds for their voluntary contributions and voluntary saving account.
} 
The Australian evidence is consistent with the U.S. experience. According to the Association of Superannuation Funds in Australia, only about 10\% of members exercise investment choice in those superannuation funds that allow members to choose the type of assets in which their superannuation is invested. $^{25}$ In addition, by June 2006, between $29 \%$ and $74 \%$ of assets in different Australia's superannuation funds are invested in the default option (see Table 7). This 'default' behaviour appears to result from participant inertia and from many employees taking the default as investment advice on the part of the company. On the other hand, the choice overload does not seem to be a problem for retail funds and investors, who face an average of 88 portfolio options.

Table 7: Proportion of asset invested in the default option in the Superannuation system

\begin{tabular}{lccccc}
\hline & Corporate & Industry & Public Sector & Retail & Total \\
\hline \hline 2004 & $65 \%$ & $70 \%$ & $64 \%$ & $55 \%$ & $61 \%$ \\
2005 & $59 \%$ & $69 \%$ & $71 \%$ & $40 \%$ & $56 \%$ \\
2006 & $58 \%$ & $74 \%$ & $61 \%$ & $29 \%$ & $49 \%$ \\
\hline
\end{tabular}

Source: Australian Prudential Regulation Authority (APRA), 2006.

In contrast to the U.S. and Australian experiences, the Swedish Premium Pension System had a large proportion of active savers during the first round of choices in 2000. Around two-third (67\%) of plan members made an active choice. Engström \& Westerberg (2003) explain this high participation rate by the effectiveness of the Swedish government's comprehensive information campaign, marketing efforts by fund companies, and considerable media attention given to the new pension system. They suggest these activities may have reduced the costs of individuals becoming informed.

However, the level of participation and the efforts to encourage active choosing have dropped over time. After the initial enrolment period, the government significantly reduced its advertisement expenditure. Interestingly, the proportion of member choosing their own portfolio fell as well. During the last four years, investment choice among first time choosers fell dramatically to less than $10 \%$ (see Table $8)$.

Table 8: Share of first-time chooser that made an active choice in Sweden

\begin{tabular}{cccccccc}
\hline & 2000 & 2001 & 2002 & 2003 & 2004 & 2005 & 2006 \\
\hline \hline $\begin{array}{c}\text { Total number of first time } \\
\text { choosers }\end{array}$ & $4,420,003$ & 492,934 & 195,851 & 150,151 & 128,991 & 116,800 & 113,450 \\
$\begin{array}{c}\% \text { of first time choosers } \\
\text { who made an active choice }\end{array}$ & $67 \%$ & $18 \%$ & $14 \%$ & $8.4 \%$ & $9.4 \%$ & $8 \%$ & $7.5 \%$ \\
\hline Source: Premium Pension Authority, 2006 & & & & & & &
\end{tabular}

The drop-off in choice in the last rounds may be explained by the characteristics of the workers and to the choice situation. Participants in later rounds are mostly young workers entering the labour market. These participants are less likely to make decision about pension because retirement is far away and they may have more immediate financial concerns. Moreover, their account balances are small and they may view that the gains from choosing a portfolio is small. ${ }^{26}$ Thus, the substantial decline in the fraction of member making active decision suggests that procrastination and inertia are important determinants of savings behaviour, at least in the short term. Furthermore, it is possible that new participants after the first

\footnotetext{
${ }^{25}$ Bowman, 2003.

${ }^{26}$ Weaver, 2005 a.
} 
round of choices may also have been overwhelmed by the staggering array of fund choices. The low levels of active choice could also be a result of choice overload.

Later, participants who did not make an active choice may have also been attracted by the higher investment return and lower management fees of the default fund During the period 2001-2005, the Premium Saving Fund (default option) has performed better than an average weighted of all funds that can be actively chosen in the PPM system (PPM Index). Although both of them recorded negative returns for the initial two years, the subsequent gains more than made-up the initial losses. During the period 20012006, the Premium Saving Fund produced an annual average return of $2.7 \%$ compared with the $2.1 \%$ for the PPM Index (see Chart 3). The default fund is also considerably cheaper than other funds. By the end of 2005 , the net fee $\mathrm{e}^{27}$ for the default option was $0.14 \%$ while the average fund fee for participants who made an active choice was $0.39 \%$ (see Chart 4 ).

Chart 3: Average annual return (2001 - 2006)

\section{Chart 4: Fund management charges after rebate}

As a \% of total assets (2002 - 2006)

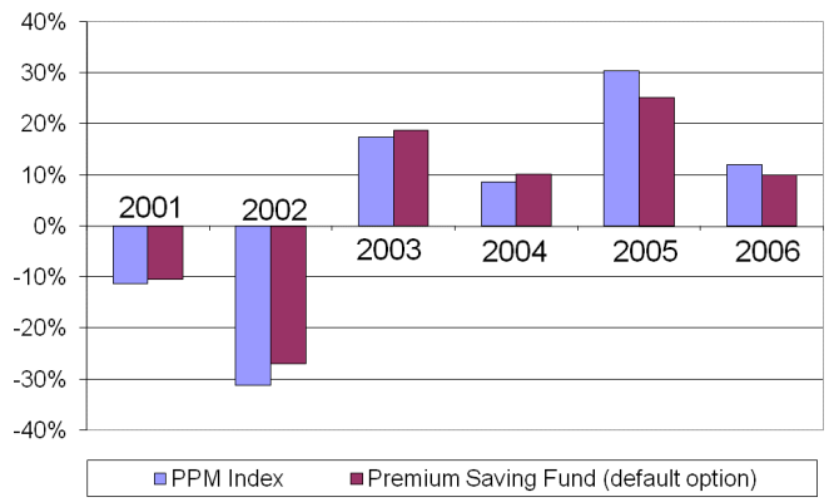

Source: Premium Pension Authority and Seventh AP Fund.

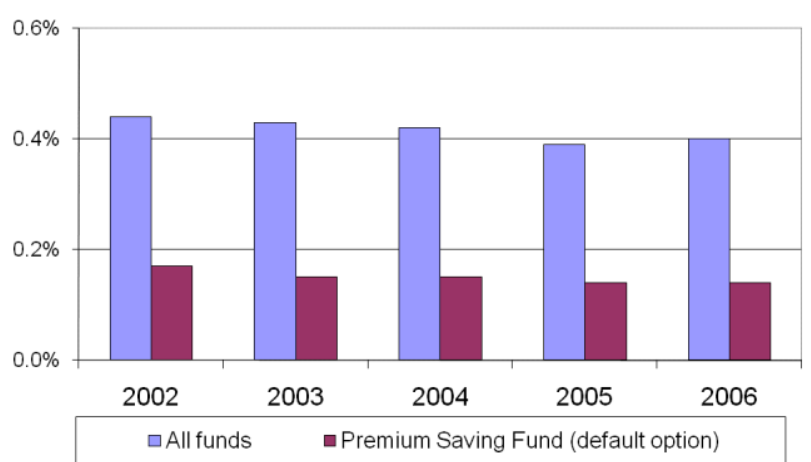

Source: Premium Pension Authority and Seventh AP Fund.

The apparent reluctance of participants to exercise active investment choice is also well supported by evidence in Latin American countries, despite the much smaller number of investment options. The first investment selections in Chile took place in 2002 when all participants were able to choose how to invest their contributions from a menu of 5 different investment options. By October 2002 approximately 14\% of participants made an "active choice" while the remaining participants' contributions were invested in the default fund. However, the proportion of active participants grew rapidly during the following years, reaching the $34 \%$ of total participants, or $74 \%$ of regular contributors (see Table 9).

Table 9: Percentage of members that made an active choice in Chile

\begin{tabular}{lccccc}
\hline & 2002 & 2003 & 2004 & 2005 & 2006 \\
\hline \hline $\begin{array}{c}\% \text { of members that made } \\
\text { an active choice }\end{array}$ & $16 \%$ & $20 \%$ & $24 \%$ & $29 \%$ & $34 \%$ \\
$\begin{array}{l}\text { Total number of members } \\
\text { Source: SAFP, } 2005\end{array}$ & 6.7 millions & 6.9 millions & 7.1 millions & 7.4 millions & 7.6 millions \\
\hline
\end{tabular}

\footnotetext{
${ }^{27}$ After discounts negotiated by the PPM, the central administrators of the PPS.
} 
An overview of the investment behaviour in Peru provides further evidence that members rely mainly on the default option, rather than making active choices of their own. By the end of 2005, only 11,600 $(0.4 \%)$ out of more than 3 millions of participants had chosen actively an investment portfolio. ${ }^{28}$ Furthermore, among these participants, around 50\% chose to remain in the balanced fund (default option), which is same fund existing before the implementation of the multifunds scheme. The rest of participants, who did not make an active choice, were assigned to the default fund according to their age.

One the main reasons to explain the low level of choice and the preference for the default option in Peru may be related to the design of the investment strategies. It is possible that the default option is appropriately designed to meet the retirement goals of participants, resulting in a preference to remain in the default fund. A second factor was the introduction of a new fund administrator with lower commissions at the same time of the implementation of investment choice. This situation changed completely the original launch for the lifestyle funds system, because companies instead of promoting the new scheme, launched an aggressive advertising campaign focused mainly on their fees. A final factor is the annual average return of the system since the inception of the system (15\% per annum). This may have affected participants' decisions, because even without making any active choice they are obtaining excellent results.

The relative passiveness of Swedish and Latin American members contrasts with the experience in Central and Eastern Europe and Hong Kong (China). The level of activity in Estonia, Latvia and Slovakia shows that the majority of participants are decisions-makers. The most recent data in the three countries shows that at least $85 \%$ of total participant in the mandatory pension system have made an active investment choice (see Table 10). Similarly, in Hong Kong (China), by the end of 2006, less than $15 \%$ of total assets were placed in the default option.

Table 10: Percentage of members that made an active choice in CEE countries

\begin{tabular}{cccc}
\hline & Estonia (2005) & Latvia (2006) & Slovakia (2006) \\
\hline \% of members & $88 \%$ & $85 \%$ & $96 \%$ \\
No. of members & 392,575 & 838,121 & $1,399,306$ \\
\hline Source: OECD, 2006 & &
\end{tabular}

\section{Investment choice by fund type}

The type of heuristic decision-making identified in the United States also appears to apply to the countries studied. Participants in the Swedish PPS invest predominately in domestic and international shares. During the initial two years, those that made active choices invested almost three-quarter of their pension capital in shares funds. However, due to the poor performance of equity funds after the inception of the individual account system (2001-2002), there was a noticeable shift to fixed income funds among active choosers in 2003. The participation of interest bearing funds (as a percentage of actively placed funds) increased from $2 \%$ in 2000 to $26 \%$ in $2003 .{ }^{29}$ Such investor behaviour reveals a bias to invest more when valuations are high and less when they are low, precisely the opposite of what rational investors should be doing.

This trend was reversed during the last two rounds of choices (2005-2006). Among first time choosers who actively selected investment funds, equity funds were the most popular choice, while fixed income funds were the least popular choice. In fact, the proportion of active members choosing only equity funds

\footnotetext{
${ }^{28}$ Superintendencia de Banca, Seguros y AFP, 2005.

${ }^{29}$ Weaber, 2005 b.
} 
increased noticeably from $39 \%$ to $59 \%$, whereas the proportion of active members choosing only fixed income funds fell from $14 \%$ to $4 \%$ (see Table 11). Moreover, among those members who chose a combination of two or more funds with different asset allocation, around $20 \%$ of them selected an equity fund as part of their investment strategy.

Table 11: Percentage of first time choosers by fund into the Premium Pension System

\begin{tabular}{ccc}
\hline & 2005 & 2006 \\
\hline \hline Only equity funds & $39 \%$ & $59 \%$ \\
Only mixed funds & $4 \%$ & $2 \%$ \\
Only generation funds & $9 \%$ & $10 \%$ \\
Only fixed income funds & $14 \%$ & $4 \%$ \\
At least one equity fund & $21 \%$ & $19 \%$ \\
At least one fixed income funds & $3 \%$ & $0 \%$ \\
Other combinations & $9 \%$ & $4 \%$ \\
Total active first time choosers & 9,331 & 8,454 \\
\hline
\end{tabular}

Source: Authors and Premium Pension Authority, 2006

Research carried out by Sunden (2004) may explain why participants in the PPS invest mainly in equity funds. She shows that the mix of investment options offered by plans in the PPS significantly affects the asset allocation of the participants in a plan. When pension providers offer many equity funds, participants tend to invest more in equities. In the Swedish Premium pension System, around $70 \%$ of the available funds are equity funds. The study also finds that the equity share in the portfolio increases with the number of funds chosen. Among participants who chose two funds, the equity share was $68.3 \%$ while the share for those who chose five funds was $83.1 \%$. This effect could be the result of the " $1 / \mathrm{n}$ " strategy identified in the United States literature.

Fund allocation in the Chilean mandatory pension funds also illustrate that active participants are taking a substantial level of equity risk in their retirement portfolios. By the end of 2006, approximately $70 \%$ of total members who made an active choice opted for those funds with an equity exposure over $60 \%$. Classifying by type of fund, the share of participants that have actively chosen fund A (up to $80 \%$ of equities) rose from $6 \%$ in 2002 to $33 \%$ in 2006 . For fund B (up to $60 \%$ of equities), this proportion has increased from 19\% to 38\% during the same period (see Chart 5). On the other hand, Fund C (up to $40 \%$ in equities), which represented the largest share of active participant at the inception of the programme fell from $55 \%$ to $24 \%$. Simultaneously, the individual preferences for those funds with the highest proportion of fixed income securities (Fund D and E) fell to 3\% and 2\% respectively. 


\section{Chart 5: Fund allocation among members that made an active choice, Chile}

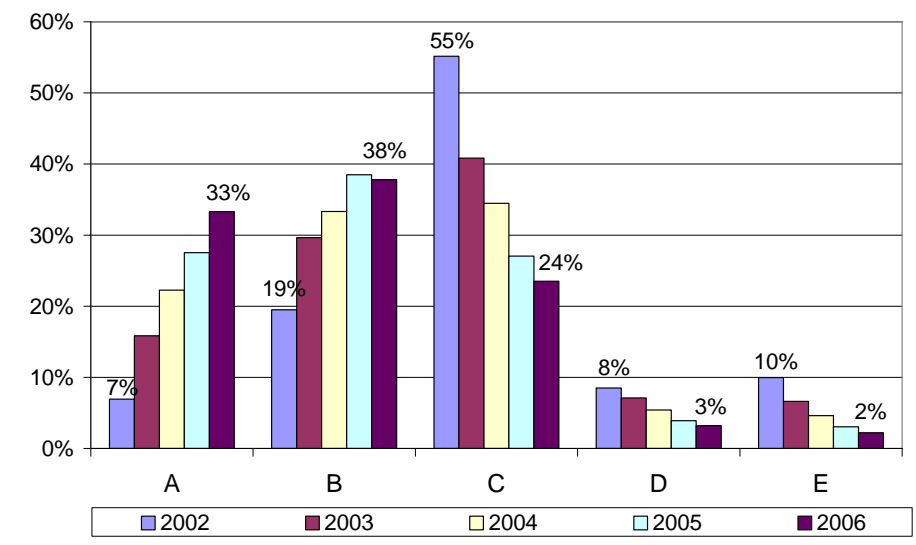

Source: Authors calculations and SAFP.

Two factors may explain why most active participants in Chile are choosing the riskiest portfolios. The first is the high returns of the equity market in Chile over the last 4 years and the second is the young structure of the population. Most financial planners advise young people to invest in funds A and B, on the basis that stock funds have historically provided higher returns than fixed income funds. Implicit in this recommendation is the expectation that the positive equity premium will continue in the future, at least over the long term. As shown in Table 12, between September 2002 and December 2006, the overall real rate of return before administrative cost of fund $\mathrm{A}$, was $96.7 \%$ in real term (17.2\% annual average return), while the result achieved by the Fund E, which is invested only in fixed income securities, was $16.9 \%$ (3.7\% annual average return).

Table 12: Invest return and number of months with negative and positive returns in the Chilean multifund pension system (Sep 2002 - Dec 2006)

\begin{tabular}{cccccc}
\hline & $\begin{array}{c}\text { Accumulated } \\
\text { real return }\end{array}$ & $\begin{array}{c}\text { annual average } \\
\text { real return }\end{array}$ & $\begin{array}{c}\text { Number of months } \\
\text { with negative yield }\end{array}$ & $\begin{array}{c}\text { Number of months } \\
\text { with positive yield }\end{array}$ & $\begin{array}{c}\text { Total period } \\
\text { (months) }\end{array}$ \\
\hline A & $96.7 \%$ & $17.2 \%$ & 13 & 38 & 51 \\
B & $63.3 \%$ & $12.2 \%$ & 12 & 39 & 51 \\
C & $45.1 \%$ & $9.1 \%$ & 12 & 39 & 51 \\
D & $32.5 \%$ & $6.9 \%$ & 10 & 41 & 51 \\
E & $16.9 \%$ & $3.7 \%$ & 14 & 37 & 51 \\
\hline
\end{tabular}

While a high allocation to equities may be appropriate given the young structure of the population (60\% of total participants are younger than 40 , while only $15 \%$ are older than 50 ), there is evidence that most members do not understand the risks involved. A survey published in $2006,{ }^{30}$ documents that only one-third of participants know how many funds there are in the investment choice scheme and only around one-fifth can give the correct total number of funds. Further, only $16 \%$ of participants know correctly their type of funds.

\footnotetext{
${ }^{30}$ Economics Department of the Universidad de Chile, 2004.
} 
Another important observation from the Chilean pension system is that most participants in each age band rely on the default option. By the end of 2006, between $62 \%$ and $79 \%$ of total participants had remained in the default allocation as their investment strategy. This result may be explained because this option meets the needs of participants. However, it is also likely that workers are convinced of its suitability precisely because it has been identified or "framed" as the default portfolio for their given age.

This "framing effect" may be demonstrated by the fact that during the last three years Chilean participants have switched actively from their default option to the fund immediately above in terms of equity exposure. This has happened in the three age bands. For example, the proportion of the first age group members whose choice correspond with their default option (fund B) has decreased from $87 \%$ in 2003 to $79 \%$ in 2006, whereas the proportion of members in the same band who have opted for fund A has increased from 5\% to $16 \%$ (see Table 13). The shift among participants in the third age band is even more significant. The proportion of members in the default option fell by 22 percentage points between 2003 and 2006, whereas the proportion in the fund immediately above in terms of equity exposure increased by 20 percentage points.

Table 13: Member allocation in the Chilean pension system by age group, 2003 - 2006 (the default option is shaded)

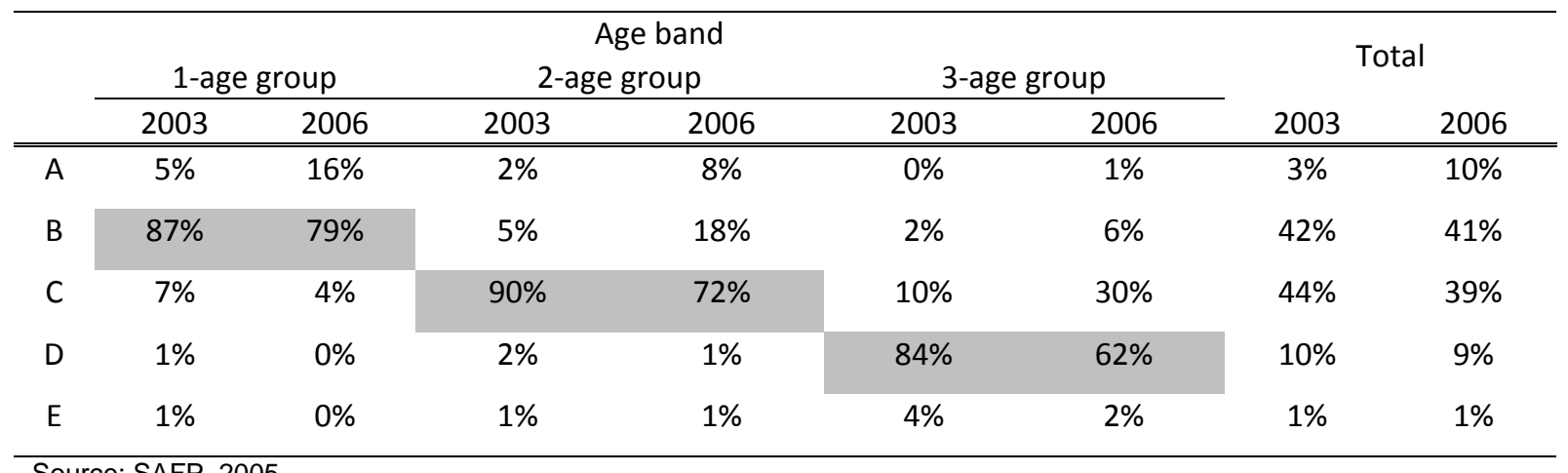

Source: SAFP, 2005.

Note: 1-age group: men and women up to 35 year old; 2-age group: men from 36 to 55 years and women from 36 to 50 years; 3-age group: men from 56 years and women from 51 and pensioners. The default option is shaded.

The analysis of the decisions made by second pillar members in Mexico shows that SIEFORE 2 (default option for members younger than 55) is the most popular investment strategy. Since the introduction of the investment choice scheme, around 34 millions of participants were allowed to choose between two investment plans offered by private asset manager. By the end of September 2006, 65\% of members were in SIEFORE 2, while the remaining 35\% were in SIEFORE 1 (see Table 14). This result should come as no surprise given that the Mexican pension system is still quite young. However, a more detailed examination of these results shows that a considerable proportion of members younger than 55 have opted for the SIEFORE 1 instead of their default option. If we classify members only according to their age structure, the proportion of members in SIEFORE 2 would be higher than 90\%, and less than $10 \%$ would qualifying in SIEFORE $1 .^{31}$

\footnotetext{
${ }^{31}$ AIOS, December 2005.
} 
Table 14: Percentage of members by investment strategy in Mexico

\begin{tabular}{lcc}
\hline \multicolumn{1}{c}{ Investment strategy } & January 1005 & September 2006 \\
\hline \hline SIEFORE 1 (investment only in fixed income securities) & $35.3 \%$ & $35.6 \%$ \\
SIEFORE 2 (up to 15\% in equities) & $64.4 \%$ & $64.7 \%$ \\
Total members (millions of members) & 33,322 & 36,459 \\
\hline
\end{tabular}

In Peru, few members selected a fund so the vast majority are placed in the balanced option with an average level of equity exposure (up to $45 \%$ ). Recent data on asset allocation reveals a slight trend towards the aggressive option (up to 80\% in equities). Between December 2005 and January 2007 the allocation in the aggressive fund grew from $1 \%$ to $7 \%$ of total assets, while those in the conservative and mixed funds decreased from $7 \%$ to $5 \%$ and from $92 \%$ to $88 \%$ respectively (see Table 15 ).

Table 15: Asset allocation in the mandatory pension system in Peru

\begin{tabular}{ccccc}
\hline Date & $\begin{array}{c}\text { Conservative } \\
\text { (no equity } \\
\text { exposure) }\end{array}$ & $\begin{array}{c}\text { Mixed } \\
\text { (up to 45\% in } \\
\text { equities) }\end{array}$ & $\begin{array}{c}\text { Aggressive } \\
\text { (up to 80\% in } \\
\text { equities) }\end{array}$ & $\begin{array}{c}\text { Total assets } \\
\text { (millions US\$) }\end{array}$ \\
\hline \hline December 2005 & $7 \%$ & $92 \%$ & $1 \%$ & 9,501 \\
January 2007 & $5 \%$ & $88 \%$ & $7 \%$ & 15,005 \\
\hline Source: Superintendenci
\end{tabular}

Source: Superintendencia de Banca, Seguros y AFP. December 2005.

Similar to the Chilean experience, this increase in the allocation to equity funds could be the result of the high returns of the stock market during 2006. In fact, during the first 12 months since the implementation of the Peruvian multifunds system, the stock market increased more than $180 \%$. As consequence of this outstanding result, the real investment return of the aggressive fund was around $90 \%$. On the contrary, the real investments return of the conservative and mixed fund during the same period was $16 \%$ and $23 \%$ respectively.

The experience in Central and Eastern European countries reveals a preference by members for equity funds. In Estonia, by the end of 2005 around $70 \%$ out of 392,595 chose the pension fund with the highest equity exposure, with up to $50 \%$ of the fund's assets in equities (see Table 16). Members who opted for the pension fund with the medium risk level, which invest up to $25 \%$ of assets into equities, represented $18 \%$. Finally, the remaining $12 \%$ of members joined the conservative option with no equity exposure. Their preferences for higher risk appear to be driven by marketing companies and advice of fund management companies. ${ }^{32}$

The analysis of demographic data in Estonia shows also that an important percentage of participants in an intermediate age and close to retirement are choosing the pension funds with the highest equity exposure. By the end of 2004, from the total number participants in the progressive fund (up to 50\% in equities) the majority of them (80\%) are younger than 40 , while the remaining $20 \%$ are members aged between 40 and 50 and older.

\footnotetext{
${ }^{32}$ PRAXIS Center for Policy Studies, July 2005.
} 
Latvia has had a similar experience. Investment choice of pension portfolio started on 1 January 2003. By June 2006 approximately $68 \%$ of total participants in the second pillar had invested their pension savings in funds with a dynamic investment policy (up to $30 \%$ in equities). The age structure of the participants in the system and the potential for higher returns from a more diversified portfolio, with a greater equity component provide two strong arguments for member choice of active portfolio. On the other side, $28 \%$ of total participants decided to invest their pension saving in the conservative strategy (no equity exposure) or failed to make an active choice (as this fund is the default option). Finally, $4 \%$ of participants opted for balanced investment plans (up to $15 \%$ in equities).

Most of the members in the mandatory private pension scheme in Slovakia have followed an aggressive investment strategy. By June 2006, most of them had chosen the riskiest investment strategy $(68 \%)$, with an equity allocation up to $80 \%$, while $28 \%$ had opted to place their pension savings in the investment strategy with up to $50 \%$ of equity allocation (balanced option). The conservative fund gathered only $4 \%$ of participants. As in the other Central and Eastern European countries, this appetite for high risk strategies is driven by the younger age structure (under 40 years old) who represent $82 \%$ of all participants (see Table 16).

Table 16: Members allocation by investment portfolio in CEE countries

\begin{tabular}{cccc}
\hline & Estonia (2005) & Latvia (June 2006) & Slovakia (June 2006) \\
\hline \hline Aggressive & $70 \%$ & $68 \%$ & $68 \%$ \\
Balanced & $18 \%$ & $4 \%$ & $28 \%$ \\
Conservative & $12 \%$ & $28 \%$ & $4 \%$ \\
\hline Source: OECD, 2006 & &
\end{tabular}

Similar to the experience in Central and Eastern European countries, balanced funds (70\% of equity exposure) and equity funds (around 100\% equity exposure) have been the most popular choice in the MPF system of Hong Kong (China). In fact, the participation of both funds as a percentage of total assets has risen by around 10 percentage points, from 63\% in 2001 to $73 \%$ in 2006 (see Chart 6). This increase is probably attributed to the increase in the stock market since the second quarter of 2003. On the other hand, the appeal of guaranteed funds (15\% of equity exposure) seems to have dropped during the same period. Most Guaranteed fund providers have slashed the rate of guarantee due to the drop in interest rates in the past few years, which make the original guarantee rate unsustainable. In view of the reduction in the guaranteed rates of returns, employees have turned to balanced and equity funds (see Chart 7). 
Chart 6: Distribution of assets by type of fund 20012005

(as a \% of total assets)

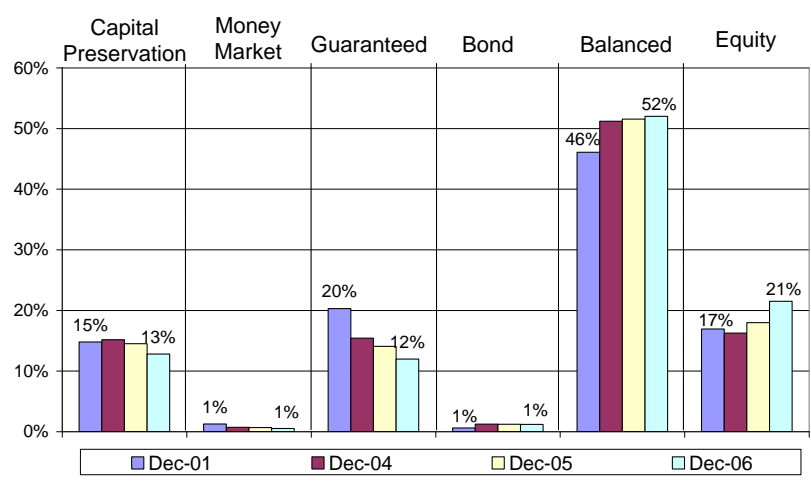

Source: MPF Authority and Authors' calculation.
Chart 7: 12-month nominal rate of return by type of fund $2002-2006$

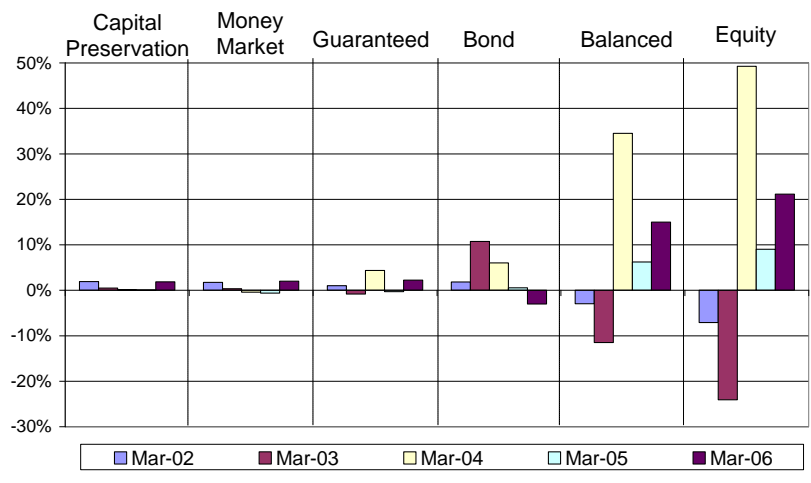

Source: MPF Authority and Authors' calculation.

\section{Concluding Remarks}

Mandatory individual retirement accounts have been introduced in various OECD countries and a large number of non-OECD ones. In most cases, these accounts have partially replaced public pension systems, raising concerns over their impact on retirement income. One of the most controversial aspects of these systems is whether and how to regulate the choice of portfolio and asset allocation by participants during the accumulation stage.

This paper's review of the international evidence on the investment behaviour of participants has identified some worrying patterns. Multiple research studies on behavioural economics have raised serious doubts about the ability of individuals to make strategic investment decisions. Although standard economic theory assumes that individuals act rationally to maximize their self-interest, behavioural economists have shown that limitations to cognitive abilities and behavioural challenges thwart the intention of many to make effective choices. The challenge facing policymakers is how to exploit the lessons of behavioural research to design investment choices that encourage individuals to make decisions that are in their own long-term interest.

An important conclusion from the empirical literature (which is largely United States-focused) is that menu design matters enormously for the choices actually made by investors. One particularly important difference among countries that have introduced mandatory individual accounts into their pension system is the number and structure of portfolio options available during the account accumulation phase. The international experience is quite varied. Countries such as Australia and Sweden offer an extraordinarily wide range of choice, whereas Latin American and Central and Eastern European countries offer a very limited number of choices (between two and five).

Although a basic assumption of economic theory is that consumers are better off with a wider array of choices, too many investment options can cause information overload, resulting in greater confusion and complexity, and, consequently, in greater use of the default option. This is confirmed by the international evidence, as the percentage of contributors who exert choice is higher in Chile (approximately 74\%) and especially in Central and Eastern European countries (over 85\%) than Australia or Sweden (less than $10 \%$ ). 
Another key policy issue is the design of the default option, since even when choice is limited, an important group of participants do not exercise active choice. Moreover, many participants may interpret the default option as the relevant one for them, as it has been endorsed or proposed by policymakers. In Hungary, Estonia and Slovakia, for instance, the default option has no equity investment, which maybe unsuitable for young participants. In contrast, in Sweden, the default fund invests over $80 \%$ of its assets in equities. The countries studied regulate the default option in radically different ways and only Latin American countries adjust it depending on the age of the participants. Policy-makers need to urgently address how default investment options should be designed and specifically consider new types of default options, such as managed accounts and target date funds.

The international evidence also reveals a preference among members towards equity funds. While the age structure of participants in Latin American and Central and Eastern European countries may justify high equity allocations, there is also evidence of heuristic biases. Participants tend to change their asset allocation on the basis of recent performance trends and engage on naive diversification strategies, such as equal weights across funds irrespective of their asset allocation.

Overall, the international evidence on investment choice in mandatory individual account pension systems largely conforms with the patters identified in the United States, the country with broadest research in this area. More detailed research is needed to confirm some of the preliminary findings of this report. 


\section{References}

Agnew, J. (2003), “Inefficient Choices in 401(k) Plans: Evidence from Individual Level Data”. Manuscript in preparation, The College of William and Mary.

Australian Prudential Regulation Authority (2006), “Annual Superannuation Bulletin”, June 2005.

Barber, B. and T, Odean (2000), "Trading is hazardous to your wealth: The common stock investment performance of individual investors", The Journal of Finance, 2, 773-806.

Bernartzi, S. and R. Thaler (1999), "Risk Aversion or Myopia? Choices in Repeated Gambles and Retirement Investments", Management Science, Vol. 45, No. 3, pp. 364-38.

Benartzi, S. and R. Thaler (2001), "Naive Diversification Strategies in Retirement Saving Plans", American Economic Review, March 91(1): 79-98.

Benartzi, S. and R. Thaler (2002), "How Much Is Investor Autonomy Worth?", Journal of Finance (57) 4: 1593-1616.

Benartzi, S. and R. Thaler (2007), "Heuristics and Biases in Retirement Savings Behavior”, mimeo.

Bowman, L. (2003), "A Matter of Choice", Money Management: August 2.

Brown, K., G. Gallery and N. Gallery (2004), "Superannuation Choice: The Pivotal Role of the Default Option", Journal Of Australian Political Economy No. 53, pp. 44-76.

Brown, J., N. Liang and S. Weisbenner (2007), "Individual Account Investment Options and Portfolio Choice: Behavioral Lessons from 401(K) Plans", NBER Working Paper No. W13169.

Campbell, J., and L. Viceira (2001), "Who Should Buy Long-Term Bonds?," American Economic Review, 91, 99-127.

Choi, J., D. Laibson, B. Madrian and A. Metrick (2003), "Passive Decisions and Potent Defaults." NBER Working Paper 9917.

Cronqvist, H. and R. Thaler (2004), "Design Choices in Privatized Social Security Systems: Learning from the Swedish Experience." American Economic Review Papers and Proceedings 94: 424-428.

Economics Department of the Universidad de Chile (2004), Encuesta "Historia Laboral y de Seguridad Social".

Engström, S. and A. Westerberg (2003), "Which Individuals Make Active Investment Decisions in the New Swedish Pension System?” Journal of Pension Economics and Finance 2: 225- 245.

Fischoff, B (1982). "For those condemned to study the past, heuristics and biases in hindsight", in Kahneman, D., Slovic, P., and Tversky, A., eds. 1982. Judgment under uncertainty: Heuristics and biases. New York: Cambridge University Press.

Huberman, G. and W. Jiang (2006), "Offering versus Choice in 401(k) Plans: Equity Exposure and Number of Funds", The Journal of Finance, Volume 61, Number 2, April 2006 , pp. 763-801(39). 
Iyengar, S. and E. Kamenica (2006), "Choice Overload and Simplicity Seeking”, University of Chicago Graduate School of Business Working Paper.

Kahneman, D. and A. Tversky (1979), "Prospect Theory: An Analysis of Decision under Risk", Econometrica.

Larrain, G (2007), "Portfolio investment in an inter-temporal setting: assessment of the literature and policy implications for Latin American pension system", OECD Working Papers on Insurance and Private Pensions 10, OECD Directorate for Financial and Enterprise Affairs, OECD.

Madrian, B. and D. Shea (2001), "The Power of Suggestion: Inertia in 401(k) Participation and Savings Behavior”, Quarterly Journal of Economics. 116(4): 1149-1187.

Mitchell, O. and S. Utkus (2003), "Lessons from Behavioral Finance for Retirement Plan Design", PRC Working Paper No. 2003-6.

Mullainathan, S. and R. Thaler (2000), “Behavioural Economics.” NBER Working Paper 7948.

Palme, M., A. Sundén and P. Söderlind (2005), "Investment Choice in the Swedish Premium Pension Plan", Center for Retirement Research at Boston College.

PRAXIS Center for Policy Studies (2005), “2005 national Strategy Report on Adequate and Sustainable Pensions: Estonia".

Rozinka E. and W. Tapia (2007), "Survey of Investment Choice by Pension Fund Members", OECD Working Papers on Insurance and Private Pensions 7, OECD Directorate for Financial and Enterprise Affairs, OECD.

Sundén, A. (2004), "How do Individual Accounts Work in the Swedish Pension System?", Issue in Brief 22. Center for Retirement Research at Boston College.

Sunstein, C. and R. Thaler (2003), "Libertarian Paternalism Is Not an Oxymoron”, University of Chicago Law Review, 70:1159-99.

Vanguard (2003), "Can there be too much choice in a retirement saving plan". Vanguard Center for Retirement Research.

Vanguard (2004), "Selecting a Default fund for a Defined Contribution Plan". Vanguard Center for Retirement Research.

Vanguard (2005), "Selection a Default Fund for a DC plan", Vanguard Centre for Retirement Research.

Vanguard (2006), "How America Saves 2006”, Vanguard Center for Retirement Research.

Weaver, R. (2005 a), "Design and Implementation Issues in Swedish Individual Pension Account”, Center for Retirement Research at Boston College.

Weaver, R. (2005 b), "Lesson from Sweden's Individual Pension Account”, Policy Brief 140, The Brooking Institutions.

Weber, E. (2003), "Who's Afraid of a Poor Old-Age? Risk Perception in Risk Management Decisions", Working Paper, Pension Research Council, Wharton School, University of Pennsylvania. 